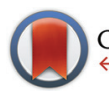

CrossMark

$\leftarrow$ click for updates

Cite this: Dalton Trans., 2016, 45 , 2805

Received 20th November 2015, Accepted 15th January 2016

DOI: $10.1039 / \mathrm{c} 5 \mathrm{dt} 04556 \mathrm{~h}$

www.rsc.org/dalton

\section{A functional mesoporous ionic crystal based on polyoxometalate $\dagger$}

\author{
Ryosuke Kawahara, ${ }^{a}$ Kazuma Niinomi, ${ }^{a}$ Junko N. Kondo, ${ }^{\text {b,c }}$ Mitsuhiro Hibino, \\ Noritaka Mizuno ${ }^{d}$ and Sayaka Uchida*a,b
}

\begin{abstract}
A mesoporous ionic crystal is synthesized with a polyoxometalate and a macrocation with polar cyano groups. The compound possesses one-dimensional mesopores with an opening of $3.0 \times 2.0 \mathrm{~nm}$. The compound shows high proton conductivity and catalytic activity, which are due to the water molecules in the mesopores.
\end{abstract}

Porous materials have attracted wide attention in chemistry due to their well-defined pore structures, which are useful in gas storage, separation, catalysis, proton conduction, and so on. According to the IUPAC definition, porous materials are divided into three classes: microporous (pore size $<2 \mathrm{~nm}$ ), mesoporous (2-50 nm), and macroporous (>50 $\mathrm{nm}$ ) materials. Zeolites and metal-organic frameworks (MOFs) are representatives of microporous materials and are utilized as adsorbents and catalysts. ${ }^{1}$ However, microporous materials have limitations in diffusion especially when large guest molecules are involved, so an important line of research has focused on the enlargement of pore sizes into the mesopore range. ${ }^{2}$

Among the mesoporous materials, MCM-41 and FSM-16 with a highly ordered array of one-dimensional pores and amorphous silica pore walls have been extensively researched. ${ }^{2}$ In addition, mesoporous organosilicates, ${ }^{3}$ non-silica metal oxides, ${ }^{4}$ metals, ${ }^{5}$ and semiconductors ${ }^{6}$ have been synthesized. Recently, mesoporous MOFs have been synthesized by the

\footnotetext{
${ }^{a}$ Department of Basic Science, School of Arts and Sciences, The University of Tokyo, 3-8-1 Komaba, Meguro-ku, Tokyo 153-8902, Japan.

E-mail: csayaka@mail.ecc.u-tokyo.ac.jp

${ }^{b}$ JST-PRESTO, 4-1-8 Honcho, Kawaguchi, Saitama 332-0012, Japan

${ }^{c}$ Chemical Resources Laboratory, Tokyo Institute of Technology, 4259-R1-10

Nagatsuta, Midori-ku, Yokohama 226-8503, Japan

${ }^{d}$ Department of Applied Chemistry, School of Engineering, The University of Tokyo,

7-3-1 Hongo, Bunkyo-ku, Tokyo 113-8656, Japan

$\dagger$ Electronic supplementary information (ESI) available: Pore sizes and volumes of porous ionic crystals (Table S1). Proton conductivities of POM-based compounds (Table S2). Thermogravimetry (Fig. S1). Solid state ${ }^{1}$ H-MASNMR (Fig. S2). Powder XRD pattern after evacuation (Fig. S3). Nyquist plots of the impedance spectra under $55-95 \%$ RH (Fig. S4). Difference IR spectrum of I treated with pyridine (Fig. S5). CCDC 1405050. For ESI and crystallographic data in CIF or other electronic format see DOI: 10.1039/c5dt04556h
}

design and modification of organic linkers and applied to asymmetric diethylzinc and alkynylzinc additions, ${ }^{7}$ co-oxidation of 4-aminoantipyrine and phenol, ${ }^{8}$ cycloaddition reaction of $\mathrm{CO}_{2}$ with carbonates, ${ }^{9}$ proton conduction, ${ }^{10}$ and so on.

On the other hand, ionic crystals (e.g., $\mathrm{NaCl}$ ) are normally non-porous because of the isotropic and long-range Coulomb interaction. ${ }^{11}$ We and other research groups have reported that the use of molecular ions with appropriate elements, charges, sizes, shapes, or ligands enables anisotropic packing and/or utilization of anisotropic interactions such as $\pi-\pi$ interactions and hydrogen-bonding, resulting in the formation of micropores. ${ }^{12}$ Strong electrostatic fields are generated at the internal surfaces of micropores due to the constituent ions, and the micropores are suitable for sorptive separation of small molecules such as $\mathrm{CO}_{2} \cdot{ }^{12 e, f}$

Polyoxometalates (POMs) are nano-sized metal-oxide macroanions with unique catalytic, electrochemical, magnetic, and luminescence properties, and have stimulated research in broad fields of science. ${ }^{13}$ Particularly, giant polyoxomolybdates with nano-sized cavities can be obtained by the aggregation of simple clusters in water under controlled-pH conditions, reducing reagents, and templates. ${ }^{14}$ Recently, nano-structured materials have been fabricated by the combination of these giant polyoxomolybdates with surfactant molecules or nanocrystals. ${ }^{15,16}$ Since POMs bear negative charges, they are potentially useful as building blocks of mesoporous compounds in combination with appropriate macrocations. However, in order to construct mesopores, a strategy is required to prevent the close-packing of ionic building blocks. In supramolecular chemistry, it is well known that hydrogen-bonded water clusters $\left(\mathrm{H}_{2} \mathrm{O}\right)_{n}$ serve as templates in the formation of complexes with nano-sized cavities, and polar functional groups or hydrogenbonding sites are often required to stabilize the water clusters. ${ }^{17}$

Based on these considerations, we synthesized a mesoporous ionic crystal $\mathrm{Cr}\left[\mathrm{Cr}_{3} \mathrm{O}\left(\mathrm{OOCCH}_{2} \mathrm{CN}\right)_{6}\left(\mathrm{H}_{2} \mathrm{O}\right)_{3}\right]_{3}\left[\alpha-\mathrm{PW}_{12} \mathrm{O}_{40}\right]_{2}$. $69 \mathrm{H}_{2} \mathrm{O}[\mathrm{I}]$ with a $\alpha$-Keggin-type POM $\left[\alpha-\mathrm{PW}_{12} \mathrm{O}_{40}\right]^{3-}$ and a macrocation $\left[\mathrm{Cr}_{3} \mathrm{O}\left(\mathrm{OOCCH}_{2} \mathrm{CN}\right)_{6}\left(\mathrm{H}_{2} \mathrm{O}\right)_{3}\right]^{+}$with polar cyano groups (CN). $\mathrm{M}(\mathrm{III})$-carboxylates $(\mathrm{M}=\mathrm{Cr}, \mathrm{Fe}, \mathrm{Mn}, \mathrm{Ru}$, etc.) with a general formula of $\left[\mathrm{M}_{3} \mathrm{O}(\mathrm{OOCR})_{6}(\mathrm{~L})_{3}\right]^{+}$have been studied as 
building blocks of solid materials because of the versatile selection of the ligands ( $R, L)$ and unique acid properties. ${ }^{18,19}$ Compound I possessed one-dimensional mesopores with an opening of $3.0 \times 2.0 \mathrm{~nm}$, and the mesoporous structure was maintained by water molecules as templates.

Compound I was obtained as green crystals via the in situ formation of $\left[\mathrm{Cr}_{3} \mathrm{O}\left(\mathrm{OOCCH}_{2} \mathrm{CN}\right)_{6}\left(\mathrm{H}_{2} \mathrm{O}\right)_{3}\right]^{+}$from $\mathrm{Cr}\left(\mathrm{NO}_{3}\right)_{3}$ and cyano acetic acid in acetone, followed by the addition of an aqueous solution containing $\mathrm{Cr}\left(\mathrm{NO}_{3}\right)_{3}$ and $\mathrm{H}_{3}\left[\alpha-\mathrm{PW}_{12} \mathrm{O}_{40}\right]$. Single crystal X-ray diffraction (XRD) analysis $\S$ showed that POMs and macrocations were arranged alternately in the $a b$ plane, and formed a ring and a mesopore with an opening of $3.0 \times 2.0 \mathrm{~nm}$ (Fig. 1a). The distances between adjacent ions in the ring were in the range of 3.142-3.330 $\AA(\mathrm{C}(\mathrm{H})-\mathrm{O})$, showing a weak hydrogen-bonding between POMs and macrocations. $\mathrm{CN}$ groups of macrocations pointed toward the center of the mesopore and interacted with the water of crystallization (see below). While the existence of $\mathrm{Cr}^{3+}$ as a counter cation was suggested by the charge balance and elemental analysis of $\mathbf{I}$, $\mathrm{Cr}^{3+}$ sites could not be determined by single crystal XRD analysis. 1 POMs and macrocations lined up along the $c$-axis, and $\mathrm{CN}$ groups of adjacent macrocations were aligned parallel to each other with distances of $3.593 \AA$, suggesting that a weak dispersion force existed between the CN groups (Fig. 1b). The void volume of I was $44.2 \%$ of the crystal lattice (11285 $\AA^{3}$ per unit cell) and was the largest among the porous ionic crystals reported to date (Fig. 1c, d and Table $\mathrm{S} 1 \dagger$ ).

Thermogravimetry (TG) (Fig. S1†) and elemental analysis suggested the existence of $69 \mathrm{~mol}$ per mol of water of crystallization. The water molecules desorbed in two steps: about 54 and $15 \mathrm{~mol} \mathrm{~mol}^{-1}$ desorbed by the treatment with dry $\mathrm{N}_{2}$ at room temperature (rt) and between $\mathrm{rt}-423 \mathrm{~K}$, respectively. Single crystal XRD analysis could locate $14 \mathrm{~mol}$ per mol of water molecules at the periphery of the mesopore. These water molecules were hydrogen-bonded to the constituent ions (i.e., oxygen atoms of POM, water ligands or CN groups of macrocation (O-O: 2.660-3.060 А, N-O: 3.111-3.119 ̊)). The solid state ${ }^{1} \mathrm{H}-\mathrm{MASNMR}$ spectrum of I showed a sharp signal at $4.8 \mathrm{ppm}$ (Fig. S2 $\dagger$ ). Since hydrogen-bonding causes a low-field shift in the ${ }^{1} \mathrm{H}$-NMR signal of water $\left(c f . \mathrm{H}_{2} \mathrm{O}\right.$ in $\mathrm{C}_{6} \mathrm{D}_{6} 0.40$ ppm, $\mathrm{H}_{2} \mathrm{O}$ in $\left.\mathrm{D}_{2} \mathrm{O} 4.79 \mathrm{ppm}\right),{ }^{20}$ a hydrogen-bonding network of water molecules is probably formed in the mesopore. Moreover, the signal was sharp like that of liquid water, suggesting that the water molecules are highly mobile.

The powder XRD pattern of $\mathbf{I}$ is shown in Fig. 2. The experimental data of I (Fig. 2b) well agreed with that calculated from the crystal structure of I (Fig. 2a), showing that the mesoporous structure is stable under ambient conditions. The pattern of I broadened after evacuation at rt (Fig. S3†), showing that water molecules are necessary to maintain the mesoporous structure. These results indicate that I shows a low porosity and BET surface area based on $\mathrm{N}_{2}$ adsorption, \| while it is well known that such kinds of host-guest systems also show interesting properties in guest-exchange, ${ }^{21}$ proton conduction, ${ }^{22}$ etc. In order to characterize the states of guests (i.e., water molecules) in the mesopores, proton conductivity

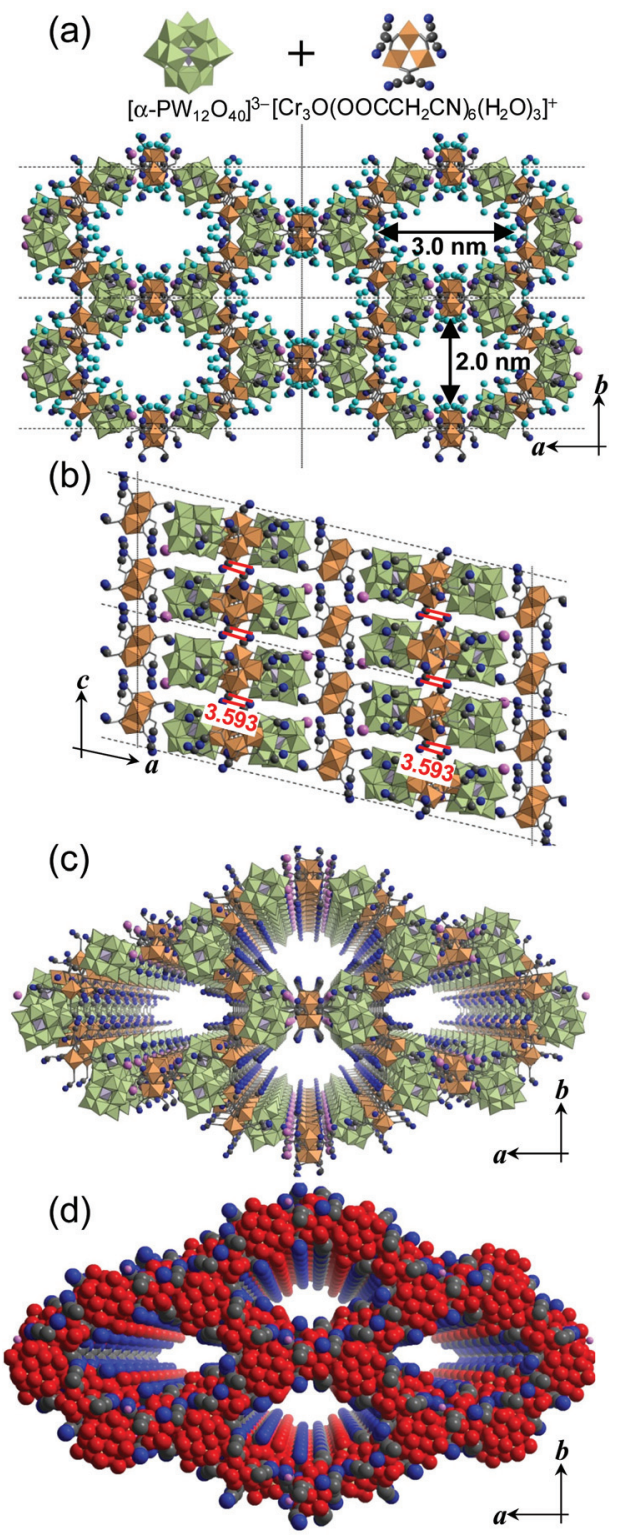

Fig. 1 (a) Molecular structures of the constituent ions and crystal structure of I (ab-plane). (b) Crystal structure of I (ac-plane). Mesoporous structure of I (ab-plane) represented in (c) polyhedral and (d) space filling models. Hydrogen atoms are omitted. Size of the mesopores $(3.0 \times 2.0 \mathrm{~nm})$ is shown in (a). Red lines in (b) show the possible dispersion force between the cyano groups. Blue and gray spheres in (a)-(c) show the nitrogen and carbon atoms, respectively, of the $\mathrm{CN}$ groups of the macrocation. Blue, gray, and red spheres in (d) are the nitrogen ( $r=$ $1.5 \AA)$, carbon ( $r=1.7 \AA)$, and oxygen ( $r=1.7 \AA$ ) atoms, respectively, depicted in their van der Waals radii. Pink and light blue spheres show the chromium ion as a counter cation and the water of crystallization, respectively. The water of crystallization is omitted for clarity in (b)-(d).

measurements and heterogeneous acid-catalyzed reactions were carried out.

Fig. 3a shows the Nyquist plots of the impedance spectra of I at $303-323 \mathrm{~K}$ under $95 \%$ relative humidity $(95 \% \mathrm{RH}) .^{* *}$ The proton conductivity estimated from the spectrum at $303 \mathrm{~K}$ was $1.0 \times 10^{-4} \mathrm{~S} \mathrm{~cm}^{-1}$, and reached up to $2.2 \times 10^{-4} \mathrm{~S} \mathrm{~cm}^{-1}$ by 


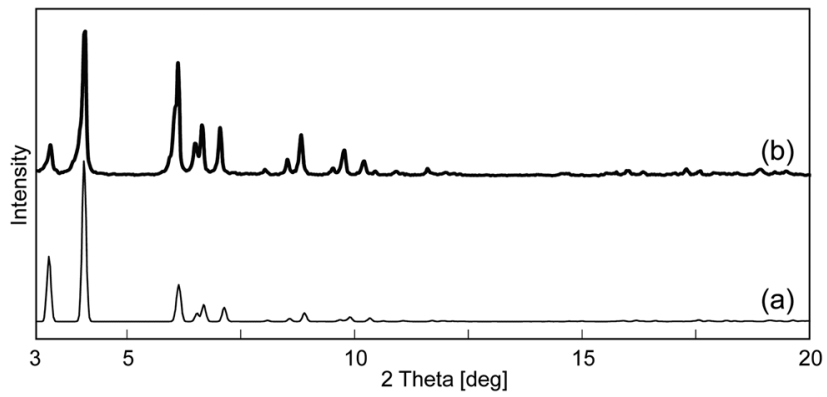

Fig. 2 (a) Calculated and (b) experimental powder XRD patterns of I.

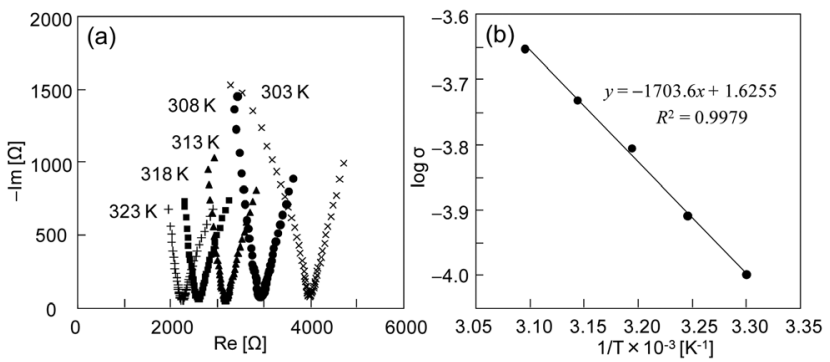

Fig. 3 (a) Nyquist plots of the impedance spectra of I at 303-323 K. (b) Arrhenius plot of the conductivities at $95 \% \mathrm{RH}$.

increasing the temperature to $323 \mathrm{~K}$. On the other hand, the proton conductivity dropped to $6.7 \times 10^{-5} \mathrm{~S} \mathrm{~cm}^{-1}$ by a decrease in $\mathrm{RH}$ to $55 \%$ (Fig. S4 $\dagger$ ). The activation energy determined from the proton conductivities at $95 \% \mathrm{RH}$ as a function of temperature using the Arrhenius equation was $0.34 \mathrm{eV}\left(32.6 \mathrm{~kJ} \mathrm{~mol}^{-1}\right)$ (Fig. 3b). While the proton conductivity $\left(1.0 \times 10^{-4} \mathrm{~S} \mathrm{~cm}^{-1}\right)$ was lower than acid hydrates of POMs (e.g., $\mathrm{H}_{3} \mathrm{PW}_{12} \mathrm{O}_{40} \cdot 29 \mathrm{H}_{2} \mathrm{O}:^{23}$ $0.18 \mathrm{~S} \mathrm{~cm}^{-1}$ at $298 \mathrm{~K}, 80 \% \mathrm{RH}$ ), the value was higher than those of POM-based salts (Table S $\uparrow$ ). The activation energy $(0.34 \mathrm{eV})$ was relatively lower than those of POM-based salts (Table $\mathrm{S} 2 \dagger$ ). The relatively high proton conductivity and low activation energy can be explained by the hydrogen-bonding network of water molecules in the one-dimensional mesopores, which facilitates the exchange and/or diffusion of protons throughout the whole bulk solid.

Porous materials based on POMs ${ }^{24}$ (POM-MOFs) have been recently studied as catalysts in aerobic oxidation, ${ }^{25}$ asymmetric dihydroxylation of olefins, ${ }^{26}$ visible-light-driven $\mathrm{H}_{2}$ production, ${ }^{27}$ and so on. The allylation of an aldehyde with allyltin (Scheme 1) is a typical acid-catalyzed reaction performed in<smiles>C=CC[AsH2+]CC(=O)c1ccccc1</smiles>

Scheme 1

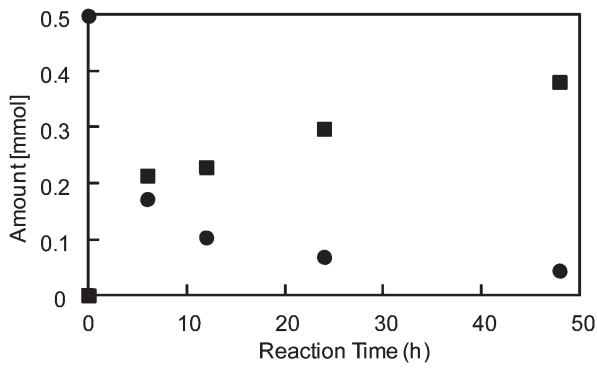

Fig. 4 Time course of the allylation of benzaldehyde with allyltin catalyzed by I ( $353 \mathrm{~K})$. Circle and square plots show the amounts of reactants and products, respectively.

water and is a useful method for $\mathrm{C}-\mathrm{C}$ bond formation. ${ }^{28}$ Fig. 4 shows the time course of changes in the amounts of the reactant (benzaldehyde) and the product (1-phenyl-3-butene-1-ol). The reaction proceeded smoothly, and the conversion and yield after $48 \mathrm{~h}$ were $91 \%$ and $76 \%$ (turn over number (TON) = 39), respectively. $+\uparrow$ The activity of I was comparable to that of scandium triflate-grafted mesoporous silica with Lewis acid sites (yield $81-91 \%$ at $353 \mathrm{~K}$ in water). ${ }^{29}+t$ The existence of acid sites in I was confirmed by IR spectroscopy: the difference spectrum of I treated with pyridine as a basic probe molecule (Fig. S5 $\dagger$ ) suggested that the pyridine molecules were adsorbed on Brønsted acid sites $\left(1534 \mathrm{~cm}^{-1}\right)$, Lewis acid sites and/or experienced hydrogen-bonding $\left(1440 \mathrm{~cm}^{-1}\right) .{ }^{30}$

This work was supported by JST-PRESTO and Grant-in-Aids for Scientific Research from the Ministry of Education, Culture, Science, Sports, and Technology of Japan. Prof. Motoyuki Matsuo and Dr Katsumi Shozugawa (Univ. of Tokyo) are acknowledged for providing access to the ICP instrument.

\section{Notes and references}

† Synthesis of $\quad \mathrm{Cr}^{2}\left[\mathrm{Cr}_{3} \mathrm{O}\left(\mathrm{OOCCH}_{2} \mathrm{CN}\right)_{6}\left(\mathrm{H}_{2} \mathrm{O}\right)_{3}\right]_{3}\left[\alpha-\mathrm{PW}_{12} \mathrm{O}_{40}\right]_{2} \cdot 69 \mathrm{H}_{2} \mathrm{O} \quad[\mathrm{I}]: \quad \mathrm{Cr}$ $\left(\mathrm{NO}_{3}\right)_{3} \cdot 9 \mathrm{H}_{2} \mathrm{O}(6.0 \mathrm{~g}, 15 \mathrm{mmol})$ and cyano acetic acid $(3.0 \mathrm{~g}, 35 \mathrm{mmol})$ were dissolved in $30 \mathrm{~mL}$ of acetone, and the solution was stirred at $323 \mathrm{~K}$ for $18 \mathrm{~h}$ (Solution A). Solution A was concentrated by evaporation followed by the addition of $280 \mathrm{~mL}$ of water. $40 \mathrm{~mL}$ of the aqueous solution was placed in a screw cap storage bottle $(50 \mathrm{~mL})$ followed by the addition of $\mathrm{Cr}\left(\mathrm{NO}_{3}\right)_{3} \cdot 9 \mathrm{H}_{2} \mathrm{O}(6.0 \mathrm{~g}$, $15 \mathrm{mmol})$ and $\mathrm{H}_{3}\left[\alpha-\mathrm{PW}_{12} \mathrm{O}_{40}\right] \cdot n \mathrm{H}_{2} \mathrm{O}(0.6 \mathrm{~g}, 0.2 \mathrm{mmol})$ in $1 \mathrm{~mL}$ of water. Green crystals of I were obtained after $24 \mathrm{~h}$ (yield 60\%). IR absorption peaks: $1655 \nu_{\text {asym }}(\mathrm{OCO}), 1437 \quad \nu_{\text {asym }}(\mathrm{CH}), 1383 \quad \nu_{\text {sym }}(\mathrm{OCO}), 1080 \nu_{\text {asym }}(\mathrm{P}-\mathrm{O}), 981$ $\nu_{\text {asym }}(\mathrm{W}=\mathrm{O}), 898 \nu_{\text {asym }}(\mathrm{W}-\mathrm{Oc}-\mathrm{W}), 818 \nu_{\text {asym }}(\mathrm{W}-\mathrm{Oe}-\mathrm{W}), 597 \nu_{\text {asym }}\left(\mathrm{Cr}_{3}-\mathrm{O}\right)$. Elemental analysis (\%) calcd for I: C 7.02, H 2.09, N 2.73, Cr 5.63, P 0.67, W 47.75; found: C 6.80, H 1.80, N 2.42, Cr 5.97, P 0.64, W 47.79.

$\S$ Single-crystal X-ray structure analysis: X-ray diffraction data of I were collected at $93 \mathrm{~K}$ with a CCD 2D detector by using a Rigaku Mercury diffractometer with graphite-monochromated MoK $\alpha$ radiation $(\lambda=0.71069 \AA)$. The structure was solved by direct methods (SHELX97), expanded by Fourier techniques, and refined by full-matrix least-squares against $F^{2}$ with the SHELXL-2014 package. CCDC 1405050 contains the supplementary crystallographic data. Crystal data for I: monoclinic C2/c (\#15), $a=57.01(2), b=24.477(11), c=18.797(7), \beta=$ 103.494(11), $V=25506(18), Z=4, R_{1}=0.0636, \mathrm{w} R_{2}=0.1841, \mathrm{GOF}=1.064$.

ๆ There are four $\mathrm{Cr}^{3+}$ in a unit cell because $Z$ is 4 . On the other hand, there are eight equivalent sites in the space group $C 2 / c$. Therefore, $\mathrm{Cr}^{3+}$ sites are intrinsically disordered. One of the oxygen atoms of the water of crystallization showed 
a relatively small isotropic temperature factor, and may be a possible candidate for the $\mathrm{Cr}^{3+}$ site. Notably, in the case of zeolites, the extraframework cations are also frequently unlocated because of severe disordering, and the locations have been suggested by computational methods. ${ }^{31}$

$\|$ Theoretical surface area can be estimated from the crystal structure of $\mathbf{I}$. There are two channel openings $(3.0 \times 2.0 \mathrm{~nm})$ in the $a b$-plane per unit cell of $\mathbf{I}$. The circumference and length of the channel are $1.6 \times 10^{2} \AA$ and $1.9 \times 10^{1} \AA$, respectively. The formula weight of I without guests is $8.0 \times 10^{3} \mathrm{~g} \mathrm{~mol}^{-1}$. Therefore, the theoretical surface area $\left[\mathrm{m}^{2} \mathrm{~g}^{-1}\right]$ of $\mathbf{I}$ can be estimated by the following equation: $\left\{2 \times\left(1.6 \times 10^{2}\right) \times\left(1.9 \times 10^{1}\right) \times 10^{-20}\right\} /\left\{8.0 \times 10^{3} \times 4 /\left(6.0 \times 10^{23}\right)\right\}=1.1 \times 10^{3} \mathrm{~m}^{2} \mathrm{~g}^{-1}$. This value is comparable to the BET surface area of mesoporous silica MCM-41 $\left(9.8 \times 10^{2} \mathrm{~m}^{2} \mathrm{~g}^{-1}\right) \cdot{ }^{32}$

**Alternating current (AC) impedance spectroscopy: impedance measurements were carried out in a thermo-hygrostat chamber (ESPEC) with a VMP3 multichannel potentiostat/galvanostat (BioLogic Science Instruments) over the frequency range of $5 \mathrm{~Hz}$ to $500 \mathrm{kHz}$. About $100 \mathrm{mg}$ of the compounds were compressed at $100 \mathrm{kgf} \mathrm{cm}$ cm$^{-2}$ into pellets of $10 \mathrm{~mm}$ in diameter and $c a .0 .5 \mathrm{~mm}$ in thickness. Gold electrodes were attached on both sides of the pellet. Bulk conductivities were estimated by a semicircle fitting of Nyquist plots. Activation energies were determined from the conductivities as a function of temperature using the Arrhenius equation.

$\dagger$ Acid-catalyzed heterogeneous reaction: The reaction was carried out in a glass reactor equipped with a magnetic stirrer. In a typical run of Barbier reaction, a mixture of benzaldehyde $(0.5 \mathrm{mmol})$, allyltributyltin $(1.0 \mathrm{mmol}), 1,4$-dioxane $(0.5 \mathrm{mmol}$, internal standard $)$, and $\mathbf{I}(0.1 \mathrm{~g}, 11 \mu \mathrm{mol})$ in water $(1 \mathrm{~mL})$ was stirred under air at $353 \mathrm{~K}$. The reaction progress was followed by gas chromatography using a GC-2014 (Shimadzu) fitted with a TC-WAX capillary column and a flame ionization detector.

$\$$ It has been reported that Dawson and Keggin-type POMs grafted with Lewis acid sites catalyze various $\mathrm{C}-\mathrm{C}$ bond formation reactions under mild conditions in organic solvents. ${ }^{33}$ In contrast, the allylation of benzaldehyde with allyltin and I was probably promoted by Brønsted acid sites as reported in ref. $28 b$, which originated from the water of crystallization.

1 (a) A. Corma, Chem. Rev., 1997, 97, 2373-2420; (b) J. R. Li, R. J. Kuppler and H. C. Zhou, Chem. Soc. Rev., 2009, 38, 1477-1504.

2 (a) A. Taguchi and F. Schüth, Microporous Mesoporous Mater., 2005, 77, 1-45; (b) K. Ariga, A. Vinu, Y. Yamauchi, Q. Ji and J. P. Hill, Bull. Chem. Soc. Jpn., 2012, 85, 1-32.

3 (a) N. Mizoshita, T. Tani and S. Inagaki, Chem. Soc. Rev., 2011, 40, 789-800; (b) B. J. Melde, B. T. Holland, C. F. Blanford and A. Stein, Chem. Mater., 1999, 11, 33023308.

4 (a) P. Yang, D. Zhao, D. I. Margolese, B. F. Chmelka and G. D. Stucky, Nature, 1998, 396, 152-155; (b) Z. Zhang and T. J. Pinnavaia, J. Am. Chem. Soc., 2002, 124, 12294-12301; (c) B. Lee, D. Lu, J. N. Kondo and K. Domen, J. Am. Chem. Soc., 2002, 124, 11256-11257.

5 Y. Yamauchi and K. Kuroda, Chem. - Asian. J., 2008, 3, 664676.

6 Y. G. S. Armatas and M. G. Kanatzidis, Nature, 2006, 441, 1122-1125.

7 L. Ma, J. M. Falkowski, C. Abney and W. Lin, Nat. Chem., 2010, 2, 838-846.

8 K. Wang, D. Feng, T. F. Liu, J. Su, S. Yuan, Y. P. Chen, M. Bosch, X. Zou and H. C. Zhou, J. Am. Chem. Soc., 2014, 136, 13983-13986.

9 M. H. Beyzavi, R. C. Klet, S. Tussupbayev, J. Borycz, N. A. Vermeulen, C. J. Cramer, J. F. Stoddart, J. T. Hupp and O. K. Farha, J. Am. Chem. Soc., 2014, 136, 1586115864.
10 V. G. Ponomareva, K. A. Kovalenko, A. P. Chupakhin, D. N. Dybtsev, E. S. Shutova and V. P. Fedin, J. Am. Chem. Soc., 2012, 134, 15640-15643.

11 D. F. Shriver, P. W. Atkins and C. H. Langford, Inorganic Chemistry, Oxford University Press, Oxford, 2nd edn, 1994.

12 (a) M. V. Bennett, L. G. Beauvais, M. P. Shores and J. R. Long, J. Am. Chem. Soc., 2001, 123, 8022-8032; (b) S. Takamizawa, T. Akatsuka and T. Ueda, Angew. Chem., Int. Ed., 2008, 47, 1689-1692; (c) X. N. Cheng, W. Xue, J. B. Lin and X. M. Chen, Chem. Commun., 2010, 46, 246248; (d) Z. Zhang, M. Sadakane, T. Murayama, N. Sakaguchi and W. Ueda, Inorg. Chem., 2014, 53, 7309-7318; (e) R. Eguchi, S. Uchida and N. Mizuno, Angew. Chem., Int. Ed., 2012, 51, 1635-1639; (f) R. Kawahara, S. Uchida and N. Mizuno, Inorg. Chem., 2014, 53, 3665-3661.

13 C. L. Hill, ed. Thematic Issue on Polyoxometalates, Chem. Rev., 1998, 98, 1-390.

14 (a) U. Kortz, A. Müller, J. van Slageren, J. Schnack, N. S. Dalal and M. Dressel, Coord. Chem. Rev., 2009, 253, 2315-2327; (b) A. Müller, S. Q. N. Shah, H. Bögge and M. Schmidtmann, Nature, 1999, 397, 48-50; (c) T. Liu, Q. Wan, Y. Xie, C. Burger, L. Z. Liu and B. Chu, J. Am. Chem. Soc., 2001, 123, 10966-10972; (d) S. Shishido and T. Ozeki, J. Am. Chem. Soc., 2008, 130, 10588-10595; (e) B. Botar, P. Kögerler and C. L. Hill, J. Am. Chem. Soc., 2006, 128, 5336-5337; (f) L. Cronin, C. Beugholt, E. Krickemeyer, M. Schmidtmann, H. Bögge, P. Kögerler, T. Kim, K. Luong and A. Müller, Angew. Chem., Int. Ed., 2002, 41, 2805-2808.

15 (a) D. G. Kurth, P. Lehmann, D. Volkmer, H. Cölfen, M. J. Koop, A. Müller and A. Du Chesne, Chem. - Eur. J., 2000, 6, 385-393; (b) S. Noro, R. Tsunashima, Y. Kamiya, K. Uemura, H. Kita, L. Cronin, T. Akutagawa and T. Nakamura, Angew. Chem., Int. Ed., 2009, 48, 8703-8706.

16 M. I. Bodnarchuk, R. Erni, F. Krumeich and M. V. Kovalenko, Nano Lett., 2013, 13, 1699-1705.

17 (a) L. J. Barbour, G. W. Orr and J. L. Atwood, Nature, 1998, 393, 671-673; (b) S. K. Ghosh and P. K. Bharadwaj, Angew. Chem., Int. Ed., 2004, 43, 3577-3580.

18 T. Fujihara, J. Aonahata, S. Kumakura, A. Nagasawa, K. Murakami and T. Ito, Inorg. Chem., 1998, 37, 3779-3784.

19 A. Vimont, J. M. Goupil, J. C. Lavalley, M. Daturi, S. Surblé, C. Serre, F. Millange, G. Férey and N. Audebrand, J. Am. Chem. Soc., 2006, 128, 3218-3227.

20 H. E. Gottlieb, V. Kotlyar and A. Nudelman, J. Org. Chem., 1997, 62, 7512-7515.

21 K. Biradha, D. Dennis, N. K. R. MacKinnon, V. K. Sharma and M. J. Zaworotko, J. Am. Chem. Soc., 1998, 120, 1189411903.

22 H. Wang, X. Xu, N. M. Johnson, N. K. R. Dandala and H. F. Ji, Angew. Chem., Int. Ed., 2011, 50, 12538-12541.

23 O. Nakamura, T. Kodama, I. Ogino and Y. Miyake, Chem. Lett., 1979, 8, 17-18.

24 (a) C. Zhao, E. N. Glass, B. Chica, D. G. Musaev, J. M. Sumliner, R. B. Dyer, T. Lian and C. L. Hill, J. Am. Chem. Soc., 2014, 136, 12085-12091; (b) W. Salomon, 
C. Roch-Marchal, P. Mialane, P. Rouschmeyer, C. Serre, M. Haouas, F. Taulelle, S. Yang, L. Ruhlmann and A. Dolbecq, Chem. Commun., 2015, 51, 2972-2975.

25 J. Song, Z. Luo, D. K. Britt, H. Furukawa, O. M. Yaghi, K. I. Hardcastle and C. L. Hill, J. Am. Chem. Soc., 2011, 133, 16839-16846.

26 Q. Han, C. He, M. Zhao, B. Qi, J. Niu and C. Duan, J. Am. Chem. Soc., 2013, 135, 10186-10189.

27 Z.-M. Zhang, T. Zhang, C. Wang, Z. Lin, L.-S. Long and W. Lin, J. Am. Chem. Soc., 2015, 137, 3197-3200.

28 (a) S. Pratihar and S. Roy, Organometallics, 2011, 30, 32573269; (b) A. Yanagisawa, M. Morodome, H. Nakashima and H. Yamamoto, Synlett, 1997, 1309-1311.
29 M. Chen, C. Liang, F. Zhang and H. Li, ACS Sustainable Chem. Eng., 2014, 2, 486-492.

30 T. Barzetti, E. Selli, D. Moscotti and L. Forni, J. Chem. Soc., Faraday Trans., 1996, 92, 1401-1407.

31 M. E. Grillo and J. Carrazza, J. Phys. Chem., 1996, 100, 12261-12264.

32 C.-Y. Chen, H.-X. Li and M. E. Davis, Microporous Mater., 1993, 2, 17-26.

33 (a) N. Dupré, P. Rémy, K. Micoine, C. Boglio, S. Thorimbert, E. Lacôte, B. Hasenknopf and M. Malacria, Chem. - Eur. J., 2010, 16, 7256-7264; (b) B. Riflade, D. Lachkar, J. Oble, J. Li, S. Thorimbert, B. Hasenknopf and E. Lacôte, Org. Lett., 2014, 16, 3860-3863. 